\title{
Prognostic importance of DNA flow cytometric variables in rhabdomyosarcomas
}

\author{
L C D Wijnaendts, J C van der Linden, P J van Diest, A J M van Unnik, \\ J F M Delemarre, P A Voûte, C J L M Meijer
}

\begin{abstract}
Aim-To determine whether DNA ploidy patterns and $S$ phase fraction offer prognostic information in patients with rhabdomyosarcoma (RMS).

Methods-DNA flow cytometry was performed on formalin fixed, paraffin wax embedded samples from primary tumours, and metastatic deposits or recurrences in 70 patients. DNA histogram analysis was done using a semiautomated cell cycle analysis program.

Results-Of the 70 primary tumours, 23 were DNA diploid, 32 DNA aneuploid, eight DNA multiploid, and seven DNA tetraploid. The prognosis for DNA aneuploid patterns was favourable, intermediate within the group of DNA tetraploid tumours and poor among patients with DNA diploid and DNA multiploid tumours $(p=0.009)$. In multivariate analysis (Cox regression model) DNA ploidy was an important independent prognostic factor, along with TNM stage, localisation, and histopathological classification. Ten out of 32 patients with a high $S$ phase fraction ( $>15 \%$ ) with primary RMS achieved long term survival in contrast to 20 out of 29 patients with a low $S$ phase fraction $(\leqslant 15 \%)(p=0.008)$. In 24 cases the DNA ploidy of cases of relapse was analysed. Of the 15 cases, in which stem line changes had occurred, 13 died of disease. No stem line changes were noted in nine cases and in this group four patients died of disease $(\mathbf{p}=0.02)$.

Conclusions-Assessment of DNA ploidy and $S$ phase fraction in primary $R M S$ and evaluation of stem line changes in cases of relapse are important variables in predicting prognosis.
\end{abstract}

(F Clin Pathol 1993;46:948-952)

Rhabdomyosarcoma (RMS) is a highly malignant tumour with varying clinical behaviour and histopathological presentation. It accounts for about half of all paediatric soft tissue sarcomas, or $6 \%$ of all childhood cancers. In the Netherlands about 25 new cases are reported each year. With the introduction of multimodal treatment over the past two decades, the overall survival of patients with RMS has improved considerably. ${ }^{12}$ Several variables for predicting patient outcome and response to treatment have been identified: anatomic site; clinical stage; sex; and histopathological subtype. ${ }^{134}$ Many children with "favourable" features, however, still respond poorly to otherwise effective treatment.

In addition to its clinical and histopathological diversity, molecular heterogeneity has been identified by the identification of cytogenetic abnormalities, such as translocation $t(2,13)(q 35-37, q 14)^{5}$ and loss of constitutional heterozygosity at loci on chromosome $11 \mathrm{p}^{6}$ To our knowledge, however, the prognostic relevance of these markers has not yet been confirmed.

The basic characteristics of cancer cells, such as alteration in the nuclear DNA content and chromosomal aberrations, may be manifest histologically by the presence of nuclear pleomorphism, an increased nuclear cytoplasmic ratio, altered chromatin density, as well as atypical mitotic figures. Yet in RMS no attempts to quantify these morphological features have been published. In contrast, the nuclear DNA content has shown to be a quantifiable variable which correlates with prognosis in a variety of malignant diseases. $^{7-10}$

\section{Methods}

Clinical data and archival formalin fixed, paraffin wax embedded tissues from the primary tumour of 98 patients diagnosed for RMS between 1968 and 1991 were retrieved from the files of the Emma Kinderziekenhuis/Antoni van Leeuwenhoek Ziekenhuis Amsterdam, the Free University Hospital of Amsterdam, and the Academic Hospital of Groningen. The mean age of the children at time of diagnosis was 6 years (range 6 months to 22 years). The male female ratio was $6: 5$. The anatomic sites of the primary tumours included head and neck ( $n=41)$; urogenital area and pelvis $(n=30)$; abdomen $(n=12)$; extremities $(n=9)$; and thorax or trunk $(n=$ 6). Adequate information about clinical stage, according to the TNM system ${ }^{4}$ was available in 95 cases. The tumours were staged as I ( $\mathrm{n}$ $=56)$, II $(n=15)$, III $(n=12)$, and IV $(n=$ 12). The mean follow up was six years (range one month to 19 years), with a mean follow up of the surviving patients of nine years (range one to 19 years).

Haematoxylin and eosin stained slides of the tumour blocks were reviewed by a panel of paediatric pathologists (JvdL, AvU, JD) and classified into embryonal RMS ( $n=53$ ), alveolar or solid alveolar RMS $(n=17)$, botryoid RMS ( $n=9)$, embryonal sarcoma $(\mathrm{n}=6)$, spindle cell RMS $(\mathrm{n}=5)$, and RMS not otherwise specified $(n=8) .{ }^{11}$ The reviewing pathologists were unaware of the results of the DNA ploidy analysis.

1117,1007 BB

Accepted for publication 1 June 1993 
Preparation of cell suspensions from the formalin fixed, paraffin wax embedded tumour specimens was performed according to a modified Hedley technique, ${ }^{12}$ applying an extra digestive step on the material remaining on the mesh after the first enzymatic treatment. DNA flow cytometry of the cell suspensions was performed after DAPI $\left(4^{\prime}, 6^{\prime}-\right.$ diaminido-2-phenyl-indole dihydrochloride) staining with a mercury lamp based Pas II Analyser (Partec, Münster, Germany).

Fibroblasts, lymphocytes, and other normal cells, always present in suspensions, were regarded as the internal standard for DNA diploid cells, depicted as the far left peak on the histogram. When only one $G_{0} / G_{1}$ peak was present, the tumour was classified as DNA diploid. Tumours with one additional $\mathrm{G}_{0} / \mathrm{G}_{1}$ peak were classified as DNA aneuploid. When there was clearly more than one aneuploid $\mathrm{G}_{0} / \mathrm{G}_{1}$ peak, the tumour was considered DNA multiploid. DNA tetraploidy was defined when the proportion of the $G_{2} / M$ cells of the diploid population exceeded $10 \%$. The DNA Index (DI) was denoted by the ratio of the modal channel number of the $\mathrm{G}_{0} / \mathrm{G}_{1}$ peak to that of normal $\mathrm{G}_{0} / \mathrm{G}_{1}$ cells. ${ }^{13}$ The coefficient of variation of the first $G_{0} / G_{1}$ peak ranged from $3-12 \cdot 7 \%$ with a mean of $6 \%$. The average $S$ phase fraction of tumour cell population(s) was determined by cell cycle analysis using the semi-automated Multicycle program (Phoenix Flow Systems, Philadelphia, USA). Histograms were considered evaluable when (1) at least 10000 nuclei were analysed, (2) the coefficient of variation did not exceed $15 \%$, and (3) tumour cells were present in stained sections taken before and after the tumour material used to prepare the cell suspension (sandwich technique).

All statistical analyses were performed using the BMDP package (BMDP Statistical Software, Los Angeles, USA). Detailed data description was computed for all features. Statistical analysis of the data was performed using $\chi^{2}$ contingency tables. Kaplan-Meier disease free and overall survival curves were plotted, and differences between the curves were analysed using the Mantel-Cox statistic. Multivariate survival analysis, to evaluate additional prognostic value of the variables studied, was performed using the Cox regression analysis model.

\section{Results}

Seventy evaluable DNA histograms were obtained. Thirty two (46\%) tumours were DNA aneuploid, 23 (33\%) DNA diploid, eight (11\%) DNA multiploid, and seven (10\%) DNA tetraploid. Patient survival was significantly correlated with DNA ploidy. A

Table 1 DNA ploidy of primary rhabdomyosarcoma in relation to survival

\begin{tabular}{lllllll}
\hline & $n$ & $\begin{array}{l}\text { DNA } \\
\text { aneuploid }\end{array}$ & $\begin{array}{l}\text { DNA } \\
\text { diploid }\end{array}$ & $\begin{array}{l}\text { DNA } \\
\text { multiploid }\end{array}$ & $\begin{array}{l}\text { DNA } \\
\text { tetraploid }\end{array}$ & p Values \\
\hline Died of disease & 36 & 11 & 15 & 7 & 3 & 0.009 \\
No evidence of disease & 32 & 21 & 6 & 1 & 4 & \\
Totalt & 68 & 32 & 21 & 8 & 7 & \\
\hline
\end{tabular}

†Incomplete follow up data in two cases of DNA diploid tumours.

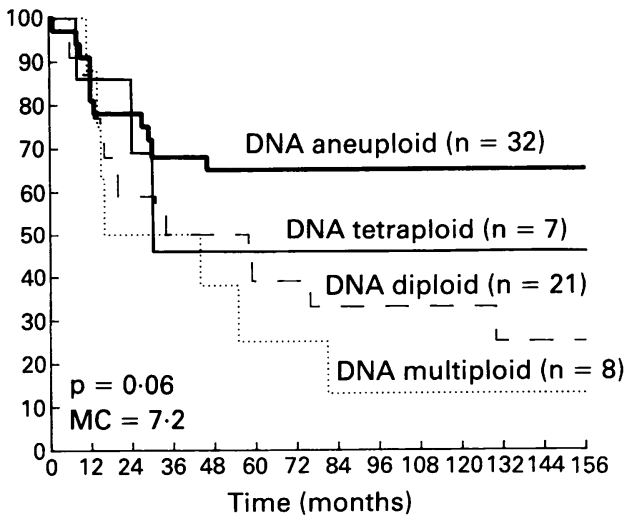

Figure 1 Kaplan-Meier overall survival curves for patients with rhabdomyosarcoma by DNA ploidy classification.

favourable prognosis was seen in patients with DNA aneuploid tumours (21 of 32 survived); prognosis was intermediate within the group of DNA tetraploid tumours (four of seven survived); and patients with DNA diploid and DNA multiploid tumours fared poorly (six of 21 and one of eight survived) $\left(\mathrm{p}=0.009 ; \chi^{2}\right.$ test) (table 1$)$. Figure 1 shows the corresponding Kaplan-Meier overall survival curves. The same trends were found for disease free survival.

In table 2 clinical variables and histopathological classification of the primary RMS are summarised in relation to the DNA ploidy pattern. Tumour localisation correlated significantly with DNA ploidy. Most tumours located in the head and neck and urogenital tract regions were DNA aneuploid (16 of 28 and 12 of 24 ) in contrast to tumours located at the extremities, abdomen, and thorax and trunk which only rarely (one of six, two of eight, and one of four) showed DNA aneuploidy ( $p=0.03 ; \chi^{2}$ test). Most tumours in TNM stage I were aneuploid (20 of 37), while TNM stage IV tumours were more often DNA diploid (six of 11) (not significant). DNA aneuploidy was more frequently seen in spindle cell RMS (three of four), botryoid RMS (four of six), embryonal sarcoma (two of two), and embryonal RMS (18 of 36) than in alveolar RMS (three of 14) (not significant). No clear correlation was seen between DNA ploidy and age and sex.

The percentage of cells in $\mathrm{S}$ phase, evaluable in 61 cases, ranged from $1.3 \%$ to $35 \%$, with a mean of $14 \%$. Ten of 32 cases with high $S$ phase fractions $(>15 \%)$ reached long term survival, but only 20 out of 29 patients with low $S$ phase fraction $(\leqslant 15 \%)$ reached long term survival $\left(\mathrm{p}=0.008 ; \chi^{2}\right.$ test). Figure 2 shows the corresponding Kaplan-Meier overall survival curves.

In a multivariate analysis, considering clinical variables (including sex, age, localisation, TNM stage I compared with TNM stage II + III + IV), histopathological classification, DNA ploidy, and $S$ phase fraction, DNA ploidy turned out to be an independent variable adding prognostic information to tumour localisation, TNM stage, and 
Table 2 DNA ploidy of primary rhabdomyosarcoma in relation to clinical variables and histopathological subtypes

\begin{tabular}{|c|c|c|c|c|c|c|}
\hline & $n$ & $\begin{array}{l}\text { DNA } \\
\text { aneuploid }\end{array}$ & $\begin{array}{l}\text { DNA } \\
\text { diploid }\end{array}$ & $\begin{array}{l}\text { DNA } \\
\text { multiploid }\end{array}$ & $\begin{array}{l}\text { DNA } \\
\text { tetraploid }\end{array}$ & p Values \\
\hline \multicolumn{7}{|l|}{ Sex } \\
\hline Male & 39 & 18 & 12 & 6 & 3 & \multirow[t]{2}{*}{0.6} \\
\hline Female & 31 & 14 & 11 & 2 & 4 & \\
\hline \multicolumn{7}{|l|}{ Age } \\
\hline$\leqslant 5$ years & 36 & 17 & 11 & 4 & 4 & \multirow[t]{3}{*}{0.8} \\
\hline $6-10$ years & 15 & 7 & 4 & 3 & 1 & \\
\hline$>10$ years & 19 & 8 & 8 & 1 & 2 & \\
\hline \multicolumn{7}{|l|}{ Localisation } \\
\hline Head and neck & 28 & 16 & 9 & 3 & 0 & \multirow[t]{6}{*}{0.03} \\
\hline Urogenital tract & 24 & 12 & 5 & 2 & 5 & \\
\hline Extremities & 6 & 1 & 1 & 2 & 2 & \\
\hline Abdomen & 8 & 2 & 5 & 1 & 0 & \\
\hline Thorax and trunk & 4 & 1 & 3 & 0 & 0 & \\
\hline \multicolumn{6}{|l|}{ TNM staget } & \\
\hline I & 37 & 20 & 11 & 3 & 3 & \multirow[t]{4}{*}{$0 \cdot 2$} \\
\hline II & 12 & 4 & 5 & 2 & 1 & \\
\hline III & 8 & 4 & 0 & 2 & 2 & \\
\hline IV & 11 & 4 & 6 & 1 & 0 & \\
\hline \multicolumn{7}{|l|}{ Histopathological subtype } \\
\hline Embryonal RMS & 36 & 18 & 10 & 4 & 4 & \multirow[t]{7}{*}{0.5} \\
\hline Alveolar RMS & 14 & 3 & 7 & 3 & 1 & \\
\hline Botryoid RMS & 6 & 4 & 2 & 0 & 0 & \\
\hline Embryonal sarcoma & 2 & 2 & 0 & 0 & 0 & \\
\hline Spindle cell RMS & 4 & 3 & 1 & 0 & 0 & \\
\hline RMS NOS & 8 & 2 & 3 & 1 & 2 & \\
\hline Total & 70 & 32 & 23 & 8 & 7 & \\
\hline
\end{tabular}

fIncomplete data in two cases.

\section{Discussion}

DNA diploidy was seen in $33 \%$ of the cases, DNA aneuploidy in $46 \%$, DNA multiploidy in $11 \%$, and DNA tetraploidy in $10 \%$ of the cases. Many authors classify DNA ploidy into two categories-DNA diploidy and nondiploidy. ${ }^{14}$ It seems, however, justified to differentiate DNA tetraploid and DNA multiploid tumours from aneuploid tumours as has been done by several other authors, ${ }^{12}{ }^{15-18}$ because of the observed divergence in clinical outcome-possibly a result of differences in tumour development. Indeed, DNA aneuploidy was a favourable prognostic factor, in contrast to DNA diploidy and DNA multiploidy (table 1). The independent prognostic value of DNA ploidy was confirmed by multivariate analysis.

Molenaar et al, ${ }^{19}$ Boyle et al, ${ }^{20}$ Shapiro et $a l^{21}$ and Chou et $a l^{22}$ suggested that DNA aneuploidy had a role in predicting patients' favourable outcome. Kowal-Vern et $a l^{15}$ did not obtain the same results, but postulated that due to the small number of cases ( $n=$ 20) studied at that time, DNA ploidy could not yet be firmly correlated with prognosis and histological findings. In contrast to adult tumours, ${ }^{23-25}$ DNA aneuploidy is a favourable prognostic factor in childhood tumours, and this has been described for neuroblastomas ${ }^{26}$ and acute lymphatic leukaemia. ${ }^{27} \mathrm{~A}$ satisfactory explanation for this has not been determined.

Although few in number $(n=8)$, patients with DNA multiploid tumours fared poorly. The high heterogeneity of these tumours, with, potentially, an increased ability to resist chemoradiotherapy, might explain this. Unfortunately, comparison with results from other studies on RMS is difficult because classification of DNA multiploid tumours has been based on the DNA index of the lowest stem line-that is, sometimes a diploid stem line. ${ }^{21}$

Assessment of $\mathrm{S}$ phase fraction in formalin fixed and waxed embedded tissues can be notoriously difficult. The recently developed Multicycle program, which offers an adequate correction for debris and sliced nuclei, made it possible to obtain reliable $S$ phase data. Long term survival correlated significantly with low $S$ phase fraction ( $\leqslant 15 \%$ ) (fig 2 ), and this agrees with other studies of paediatric tumours such as neuroblastomas. ${ }^{26} 28$ Further studies are in progress in which $S$ phase data are being compared with proliferation markers, such as PCNA and MIB $1 .{ }^{29} 30$

In 24 cases tissue samples from the primary tumour and relapsed tumour were available. Evaluation of the DNA ploidy showed a major change in the DNA ploidy of the relapse tissue in 15 of the 24 cases; the other nine cases showed no major changes (table 3 ). The occurrence of changes in DNA ploidy pattern after chemo and radiotherapy have been described..$^{22}$ 31-33 In our view, these changes rely partially on tumour heterogeneity. Therefore, due to sampling error or selective proliferation of initially undetected tumour population(s), stem line(s) may become manifest. Alternatively, tumour cell survival

\begin{tabular}{|c|c|c|c|c|}
\hline & $n$ & $\begin{array}{l}\text { Died } \\
\text { of disease }\end{array}$ & $\begin{array}{l}\text { No evidence } \\
\text { of disease }\end{array}$ & $p$ Value \\
\hline $\begin{array}{l}\text { No major change } \\
\text { Major change } \\
\text { Total }\end{array}$ & $\begin{array}{r}9 \\
15 \\
24\end{array}$ & $\begin{array}{r}4 \\
13 \\
17\end{array}$ & $\begin{array}{l}5 \\
2 \\
7\end{array}$ & 0.02 \\
\hline
\end{tabular}


Figure 3 Three examples of major changes in ploidy pattern between primary and corresponding relapse. (A) DNA multiploid primary tumour $(D I=$ $1 \cdot 79$ and $2 \cdot 1$ ); (B) DNA tetraploid relapse $(D I=$ 1.96); (C) DNA diploid primary tumour $(D I=$ 1.0); (D) DNA tetraploid relapse $(D I=1.97) ;(E)$ $D N A$ aneuploid primary tumour $(D I=1 \cdot 5) ;(F)$ DNA multiploid relapse $(D I=1.5$ and 1.79$)$.
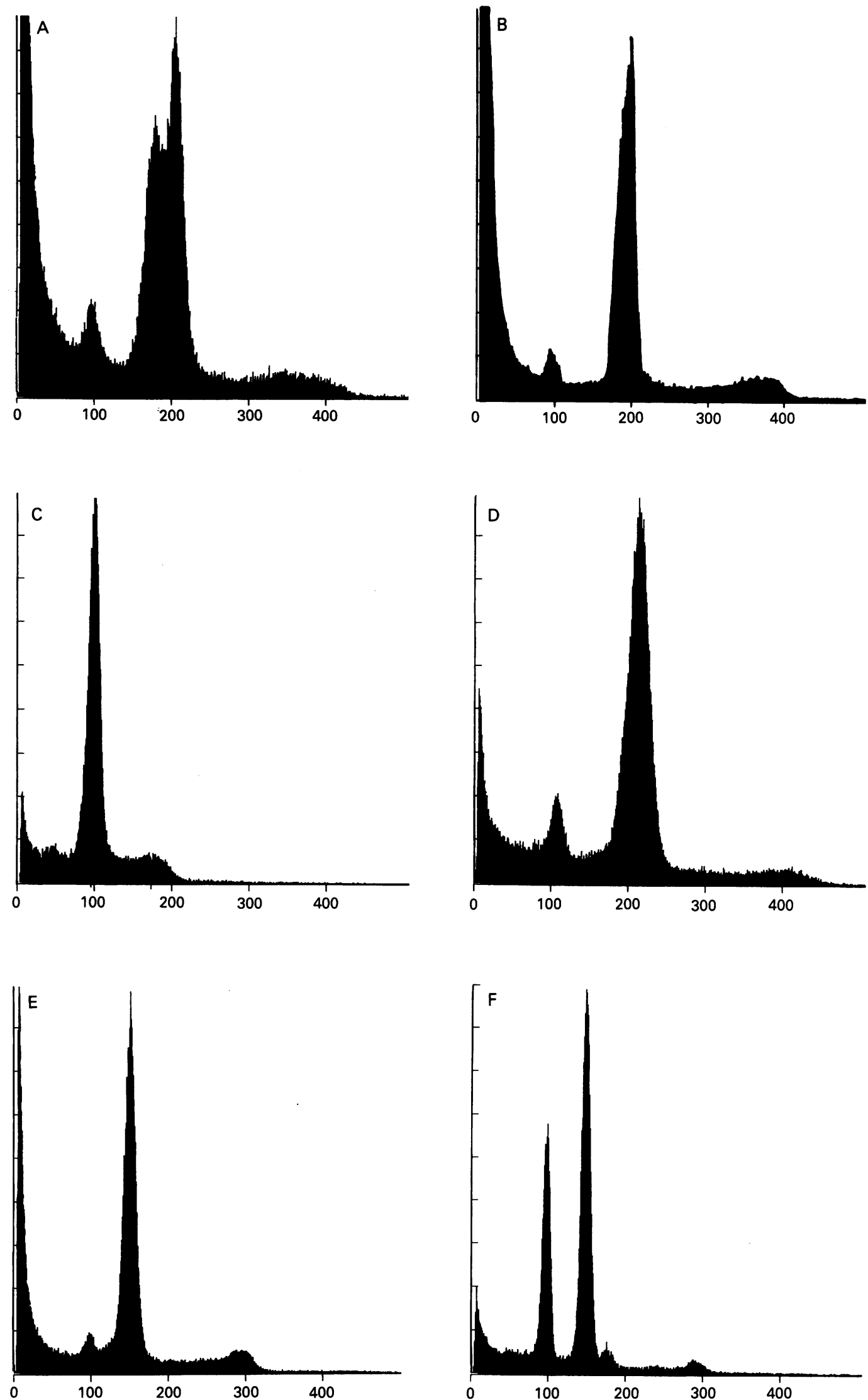

population(s) susceptible to chemotherapy and radiotherapy might be eradicated. Furthermore, genetic instability may lead to the development of new stem line(s). Interestingly, evidence was presented for the importance of monitoring changes in DNA ploidy in patients with RMS during follow up. Indeed, poor survival correlated signifi- cantly with major change in DNA ploidy, irrespective of localisation, clinical stage, and histopathological subtype.

It would be interesting to investigate whether major DNA ploidy changes in relapsed tumours are associated with the expression of P-glycoprotein in tumour cells. ${ }^{34}$ 
We thank the Werkgroep Kinder Tumoren (WKT), the Academic Hospital of Groningen, and other pathologists and clinicians who kindly provided tissue materials and clinica data. Professor J P A Baak is thanked for his continuous encouragement. J W Theeuwes, J A M Belien, and L T Schuurmans are thanked for their assistance with the flow cytometric procedures and statistical analysis.

1 Rodary C, Rey A, Olive D, et al. Prognostic factors in 281 children with nonmetastatic rhabdomyosarcoma (RMS) children with nonmetastatic rhabdomyosarco

2 Gehan EA, Lawrence W, Hays DM, Maurer HM. Pretreatment staging system for pediatric rhabdomyosarcoma patients. Proc Am Soc Clin Oncol 1988;7:255.

3 Lawrence W, Gehan EA, Hays DM, Beltangady M, Maurer HM. Prognostic significance of staging factor of the UICC staging system in childhood rhabdomyosarcoma: A report from the intergroup rhabdomyosarcoma study (IRS-II). $f$ Clin Oncol 1987;5:46-54.

4 Pedrick TJ, Donaldson SS, Cox RS. Rhabdomyosarcoma: the Stanford experience using a TNM staging system. $\ngtr$ Clin Oncol 1986;4:370-8.

5 Sheng W-W, Soukup S, Ballard E, Gotwals B, Lampkin B. Chromosomal analysis of sixteen rhabdomyosarcoB. Chromosomal analysis of

6 Scrable HJ, Witte DP, Lampkin BC, Cavenee WK sarcoma locus by mitotic recombination mapping. sarcoma locus by mi
Nacure 1987;329:645-7.

7 Koss L, Czerniak B, Herz F, Wersto R. Flow cytometri measurements of DNA and other cell components in human tumors: A critical appraisal. Hum Pathol 1989, 20:528-48.

8 Dressler L, Bartow S. DNA flow cytometry in solid tumors: practical aspects and clinical applications. Semin Diagnost Pathol 1989;6:55-82.

9 Hedley D. Flow cytometry using paraffin-embedded tissue: five years on. Cytometry 1989;10:229-41.

10 Auer G, Askensten U, Ahrens O. Cytophotometry. Hum Pathol 1989;20:518-27.

11 Wijnaendts LCD, Linden JC van der, Unnik AJM van, Delemarre JFM, Voûte PA, Meijer CJLM. Histopathologic classification of childhood rhabdomyosarcomas; Relationship with clinical parameters and prognosis. (submitted)

12 Thiel ThPH van, Linden JC van der, Sandt MM van de, Galen C van, Bezemer PD. Reproducibility of flow cytometric assessment of follicular tumours of the thyroid. $₹$ Clin Pathol 1989;42:260-3.

13 Hedley DW, Friedlander ML, Taylor IW, Rugg CA, Musgrove EA. Method for analysis of cellular DNA Musgrove EA. Method for analysis of cellular DNA content of paraffin-embedded pathological material using flow.

14 Wersto RP, Liblit RL, Koss LG. Flow cytometric DNA analysis of human solid tumors: A review of the interpretation of DNA histograms. Hum Pathol 1991;22: 1085-8.

15 Kowal-Vern A, Gonzalez-Crussi F, Turner J, et al. Flow and cytometric DNA analysis in rhabdomyosarcoma. Cancer Res 1990;50:6023-7.

16 Friedlander $M$. Flow cytometric analysis in quantitative pathology. In: Baak JPA, ed. Manual of quantitative pathology in cancer diagnosis and prognosis. Berlin pathology in cancer diagnosis

17 Joensuu H, Kallioniemi OP. Different opinions on classifi- cation of DNA histograms produced from paraffinembedded tissue. Cytometry 1989;10:711-7.

18 Kowal-Vern A, Walloch J, Chou P, et al. Flow cytometric DNA analysis in Ewing's sarcoma. Mod Pathol 1992, 5:56-60.

19 Molenaar WM, Dam-Meiring A, Kamps WA, Cornelisse CJ. DNA-aneuploidy in rhabdomyosarcomas compared with other sarcomas of childhood and adolescence. Hum Pathol 1988;19:573-9.

20 Boyle ET, Reiman HM, Kramer SA, Kekalis PP, Rainwater LM, Lieber MM. Embryonal rhabdomyosarcoma of the bladder and prostate: nuclear DNA patterns studied by flow cytometry. $\mathcal{f}$ Urol, (part 2) 1988;140:1119-21.

21 Shapiro DN, Parham DM, Douglass EC, et al. Relationship of tumor-cell ploidy to histologic subtypes and treatment outcome in children and adolescents with unresectable rhabdomyosarcoma. f Clin Oncol 1991;9: 159-66.

22 Chou P, Shen-Schwarz S, Mangkornkanok M, Crawford S, Gonzalez-Crussi F. DNA analysis of genitourinary rhabdomyosarcoma in children. Surg Pathol 1991;4: 145-55.

23 Barlogie B, Raber MN, Schumman J, et al. Flow cytometry in clinical cancer research. Cancer Res 1983;43: try in clini

24 Clark GM, Dressler LG, Pounds G, et al. Prediction of relapse or survival in patients with node-negative breast relapse or survival in patients with node-negative breast cancer by $D$

25 Merkel DE, Dressler LG, McGuire WL. Flow cytometry, cellular DNA content, and prognosis in human malig nancy. F Clin Oncol 1987;5:1690-703.

26 Gansler T, Chatten J, Varello M, Bunin GR, Atkinson B Flow cytometric analysis of neuroblastoma: Correlation with histology and clinical outcome. Cancer 1986; 58:2453-8.

27 Tsurusawa M, Katano N, Kawai S. Prognostic implication of the cellular DNA content in acute lymphoblastic leukemia. Am $₹$ Pediatr Hematol Oncol 1988;10:75-80.

28 Carlsen NLT, Ornvold $\mathrm{K}$, Christensen II, Laursen $\mathrm{H}$ Larsen JK. Prognostic importance of DNA flow cytometrical, histopathological and immunohistochemical metrical, histopathological and immunohistochemical parameters in neuroblast

29 Benjamin DR. Proliferating cell nuclear antigen (PCNA) and pediatric tumours: Assessment of proliferative activity. Ped Pathol 1991;11:507-19.

30 Cattoretti G, Becker MHG, Key G, et al. Monoclona antibodies against recombinant parts of the Ki-67 antigen (MIB1 and MIB2) detect proliferating cells in microwave-processed formalin-fixed paraffin sections. Pathol 1992;168:357-63.

31 Berg van den E, Molenaar WM, Hoekstra HJ, Kamps WA, de Jong B. DNA-ploidy and karyotype in recurrent and metastatic soft tissue sarcomas. Mod Pathol 1992, 5:505-14.

32 Allsbrook WC, Stead NW, Pantazis CG, Houston JH Crosby JH. Embryonal rhabdomyosarcoma in ascitic fluid. Immunocytochemical and DNA flow cytometric study. Arch Pathol Lab Med 1986;110:847-9.

33 Fox MH, Armstrong LW, Withrow SJ, et al. Comparison of DNA aneuploidy of primary and metastic spontaneous canine osteosarcomas. Cancer Res 1990;50. 6176-8.

34 Ling V. P-glycoprotein and resistance to anticancer drugs. Cancer 1992;69:2603-9. 